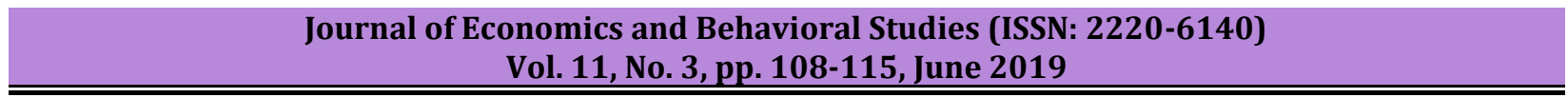

\title{
Assessment of Bank Technology Machine and Mobile Banking as Market Strategies to Raising Performance of Banks in Nigeria
}

\author{
Anthony O. Adaramola, Funso T. Kolapo \\ Department of Finance, Faculty of Management Sciences, Ekiti State University, Ado Ekiti, Nigeria \\ anthony.adaramola@eksu.edu.ng, realvega1959@gmail.com
}

\begin{abstract}
The market challenge in form of increasing competition for success in the banking sector calls for market strategies that are customer- based towards raising the performance of Nigerian banks. The use by banks, of Automated Teller Machines and Mobile banking are at the centre stage of this market strategy. Existing knowledge on this aspect of marketing is inadequate. This study assessed the empirical effects of Automated Teller Machine and Mobile banking as marketing tools on return on equity of banks in Nigeria. Both primary and secondary data were used in the study. The data were fitted to Panel regression models of Fixed and Random effects. Findings support increasing distribution of Teller machines and raising awareness on Mobile banking as result-oriented marketing strategy for banks.
\end{abstract}

Keywords: Market Strategy, ATM, Mobile Banking, Return on Equity, Banks.

\section{Introduction}

The 2004 Nigerian banking sector reforms were aimed at achieving an efficient and sound financial sector. The launching of the reforms led to a favourable competition in the banking sector. The necessity for banks to deliver high quality service with a view to surviving in the newly created competitive atmosphere becomes imperative. The use of service delivery technology was considered an ideal tool of business diversification to achieve this objective. Up to this period of reforms, banks largely utilized branch network as the major service delivery channel. Rapidly, options for various delivery channels were opened up through technological innovation. Products, for example, the automated teller machine (ATM) and mobile banking, gave the banks and the customers a number of service options to run banking business. While the use of ATM as a bank technology machine has become widely accepted in the Nigerian banking market, the Mobile banking system of delivery is still diffusing as the use of mobile technology in the form of smart phones spread among the Nigerian populace. Particularly, the advent and adoption of sophisticated mobile phones has led to rising demand for mobile banking.

Products and the need for banks to take advantage of this innovative service to boost their service delivery to customers (Shaikh \& Karjaluoto, 2015 as a result of the increasing competition in the banking industry, the primary objective of raising performance through increasing return to banks requires effective understanding of customer needs and the appropriate channels to meet their transactional goals. This is more pertinent considering the spate of bank failure in the Nigerian banking space (Onyekwelu \& Onyeka, 2014). For example, the Nigerian banks' performance outlook reflects high level of instability and volatility over the years (Table 1). Since the period following the year 2004 reforms, commercial banks' performance outlook has shown unstable trend up till 2017. As at 2009, the performance outlook was high relative to the previous years and reached its peak in 2010. Since then, the trend has been unstable by falling and rising intermittently till the year 2017. This performance outlook of the banks implies that banks need to shift focus and embrace practices that will assist in identifying consumer needs and provide services for better performance. This necessitated the need for clearer understanding of sound marketing approach in form of service delivery for a stable policy direction. 


\begin{tabular}{lc} 
& $\begin{array}{c}\text { Journal of Economics and Behavioral Studies (ISSN: 2220-6140) } \\
\text { Vol. 11, No. 3, pp. 108-115, June 2019 }\end{array}$ \\
\hline \hline & ROA \\
\hline Table 1: Performance Outlook of Banks in Nigeria \\
\hline Period & 2.096 \\
2005 & 1.754 \\
2006 & 2.669 \\
2007 & 2.105 \\
2008 & 2.748 \\
2009 & 3.800 \\
2010 & 0.419 \\
2011 & 3.269 \\
2012 & 2.051 \\
2013 & 1.753 \\
2014 & 1.639 \\
2015 & 2.838 \\
2016 & 3.123 \\
2017 & \\
\hline
\end{tabular}

Source: CBN statistical report, 2017

Several studies have analysed service delivery channels in Nigeria. However, findings on impact of product distribution outlets on bank performance in Nigeria are inconclusive. Ali and Emenike (2016) found that ATM transactions have positive effect on current account holding by individuals and companies in Nigeria. However, their time and savings accounts are not significantly affected. Further, Abaeneve, Ogbulu and Ndugbu (2013) found that delivery channels have no impact on performance, whereas Adewoye (2013) concluded that channels had significant effect. Findings from later studies such as Tijani and Ilugbemi (2015); Jegede (2014); Oginni, Mohammed, El-maude and Arikpo (2013) on the subject matter are also mixed with some of the studies finding negative effect and others positive effects of service delivery channels on performance. It is instructive to note that while all the foregoing studies were carried out in Nigeria.

The results of other studies carried out in Kenya (Awinja, 2015; Kombe \& Wafulu, 2015; Mazwile, 2014; Mukhongo, Maokomba \& Musiega, 2014) and India (Malhotra \& Singh, 2009) aligned with Nigeria's. Furthermore, specific focus on ATM and mobile banking which adequately represent the modern service delivery modes remains limited. An evaluation of the two delivery channels with their peculiarities to the Nigerian banking environment represents an important milestone in positioning the banking sector for a stable development and a good insight into the field of bank marketing. This study also provides an up-todate insight into the marketing effect of the delivery channels to bank performance. This study is particularly significant since the findings of existing studies are in contradiction to one another. Accordingly, this study is carried out to broaden the understanding of service delivery channels with specific focus on ATM and Mobile banking technologies by examining their effect on return on equity of banks in Nigeria.

\section{Literature Review}

Service delivery channels options are increasing with advancement in technologies. They represent platform through which banks interface with their numerous customers (Imafidon, 2013). Service delivery channels, according to (Karmarkar \& Pitbladdo, 2009) imply any delivery methods through which financial services can be provided to customers. Delivery channel could therefore be viewed as service distribution outlet whereby organizations offer its services to customers. Banks' service delivery channels consist of branch networking, ATMs, online channels such as e-banking, m-banking across the existing multi-channel mix in the financial market, the channels require no physical or one-on-one interaction with employees and management of banks. Thus, they are referred to as promoters of sales growth and improved satisfaction of consumers target with the benefit of reducing business risks. As noted by Oloruntoyin and Olanloye (2012), the channels are apparatuses for safe and efficient transfer of monetary value in exchange for tangible and intangible products and financial securities. 
Specifically, Okafor, (2008) perceived the ATM is an electronic gadget that offers customers easier and safer right to their accounts; enables them make cash deposit, withdraw and obtain account statements without physical presence at the banking hall through cards. According to Karmarkar and Pitbladdo (2009), service delivery channel is any delivery method through which organizations offer their services to customers. Depending on peculiarity of an organization, this collection of delivery outlets is commonly referred to as the organization's multi-channel mix. For instance, banks' service delivery channels being routine banking product or service from the bank to the customer consists of ATMs, branch networking, agency, online channels such as e-banking, m-banking et cetera. Awinja (2015) argued those channels which do not require physical contact with bank staff are referred to as 'direct channels. Multi-channel distribution has several advantages ranging from enhancing sales growth, improving customer satisfaction and reducing cost (Lovelock \& Young, 2011).

It replaces erstwhile high for low cost channels, improves means of connecting banks with market, decreases banking risk exposure and diversifies scope of bank business and thus leads to enhanced business operation. Additionally, Dzombo, Kilika and Maingi (2017) evaluated the individual and combined impact of branchless banking, agency banking and online service channels on banks' profitability in Kenya. They submitted that, in isolation, electronic and agency banking have inverse effects on profitability. However, the combination of electronic and agency methods have increasing impact on business outcome. Similarly, Kiragu, (2017) evaluated the impacts of e-banking on bank profitability in Kenya. Using probability sampling which entailed simple but random and stratified sampling, a sample of sixty (60) respondents was obtained and primary data were collected using questionnaires. Secondary data were also collected from banks financial statements. Analysis carried out using descriptive statistics showed that online banking had positive influence on service delivery and bank performance. Further, Ali and Emenike (2016) in a similar study observed that demand deposit has a direct and significant relationship with ATM transactions while savings and time deposits are not significantly affected by ATM.

Furthermore, Awinja (2015) evaluated the extent of usage and cause-effect relationship between service delivery channels and bank operational efficiency in Kenya. Findings reveal that ATMs give customers easier access to bank services and also enhanced the efficiency of banks in service delivery. In addition, mobile banking is found to lower operational costs, enhance convenience, and save time for customers. In addition, branch banking enhances geographical market, increases the size of the banks and attracts new customer while online services provided extra expediency and flexibility to users, eliminating the barriers of distance/time for unimaginable distant customers. Additionally, Tijani and Ilugbemi (2015) studied the effect of electronic payments outlets on economic development via investigation of demand and savings deposits holders in Ado-Ekiti metropolis. The results of the chi-square analysis revealed that online payment outlets have positive effect on national development and economy. In Kenya, Kombe and Wafula (2015) examined the effects of electronic banking on bank operation using a descriptive survey design targeting thirty one (31) employees of KCB. The study showed that ICT adoption positively impacted the banking sector performance mainly through services time reduction and quality improvement, as opposed to reductions in costs. Additionally, Mazwile (2014) investigated the effect of online banking on product distribution and customer satisfaction.

The study showed that electronic financial products have attendant benefits in terms ease of usage, cost effectiveness and speed with which services are delivered. These benefits lead to high customer satisfaction. Mukhongo, Maokomba and Musiega (2014) also investigated the effects of different service channels on bank profitability in Kenya by obtaining data from bank staff, customers and agents. The study observed the need for banks to design faster and customer-friendly services in order to attract the unbanked segment. Jegede (2014) investigated the link between ATM related challenges, the concomitant financial loss and bank performance in Nigeria. Questionnaires were administered on staff of sampled banks in Lagos metropolis. The results of chi-square analyses showed that the employments of automatic banking machines have averagely improved bank performance but imposed pains on the banks going by the alarming rate of ATM fraud. Findings further revealed that there is low relationship between ATM service quality and user's security and privacy. Abaeneve, Ogbulu, and Ndugbu (2013) evaluated the link between online banking and bank performance in Nigerian. Analyses were carried out on pre- and post-implementation of online banking. 
The study showed that returns on shareholders' equity is significantly and positively influenced by the implementation of internet banking in Nigerian.

Conversely, effect of e-banking is not reflected on returns on assets. Moreover, Oginni, Mohammed, El-maude and Arikpo (2013) also investigated the impact of e-banking on the profitability of Nigerian banks between 2000 and 2010. Regression results show that it takes averagely two years for e-banking to have positive impact on bank performance whereas the effect of e-banking is negative in the first year of adoption. The primary data was obtained through structured questionnaire to gauge the advantage obtained by the banks from the usage of service delivery channels in the selected banks. By administering questionnaires to staff of commercial banks in Lagos metropolis, Adewoye (2013) examined the effect of mobile banking on distribution of bank products in Nigerian. Findings from the Chi- square analyses disclosed that the positive effect of mobile banking on service delivery evidently through ease and speed with which transaction are conducted prompt transaction notification and reduced service cost resulted in improved customer satisfaction. Moreover, Malhotra and Singh (2009) analysed the impact of electronic banking on risk and performance through a survey of Indian banks. Results show that banks offering internet products are bigger and efficient compared to others.

\section{Methodology}

This study adopted a quantitative research design. Primary and secondary data were used for the study, specifically focusing on Southwestern geopolitical zone which is the economic hub of Nigeria. In addition, internet banking has a significant and inverse relationship with banks' risk rating. The secondary data covers variables on return on equity to measure performance, numbers and volume of ATM and mobile banking transactions. A total eight (8) systematically important banks (SIBs) in Nigeria were purposively selected for the study. They include: First Bank of Nigeria plc. Diamond Bank Plc. Eco bank Plc. United Bank for Africa, Guaranty Trust Bank Plc. Access Bank Plc. Polaris Bank Plc. and Zenith Bank Plc, the selected banks account for over $71 \%$ total banking sector business in Nigeria (Business Day, June 10, 2016). The secondary data covers the period between 2005 and 2016. A total of 1200 bank staff and 300 bank customers were randomly sampled out of the 1204 commercial bank branches of the eight commercial banks in Southwest Nigeria using Yamane (1967) formula. The primary data collected were analysed using descriptive statistics while panel regression techniques were employed for analyses of the secondary data over the period under investigation. The panel regression models estimated in this study are presented below.

Pooled Panel Regression Models: It is assumed under Pooled panel model that any heterogeneity across banks has been averaged out. As such, the pooled effect model is specified thus:

$$
R O E_{i t}=\beta_{0}+\beta_{1} A T M_{i t}+\beta_{2} M B K_{i t}+\beta_{3} S I Z_{i t}+\varepsilon_{i t}
$$

Fixed Panel Regression Model: It is assumed under fixed effect model that heterogeneity of individual firm is captured by the constant term. It implies that each firm was assigned a constant $\alpha_{i}$ whereas the slope coefficients are not different, and the heterogeneity is associated with the independent variables. In equation (2), a dummy is assigned to each bank, such that:

$$
R O E_{i t}=\beta_{0}+\beta_{1} A T M_{i t}+\beta_{2} M B K_{i t}+\beta_{3} S I Z_{i t}+\sum_{i=1}^{15} \alpha_{i} i d u m+\varepsilon_{i t}
$$

Where $\alpha_{i}$ idum represents a dummy variable and $a_{i}$ is an unobserved effect

Random Effect Model: It is assumed under random effect model that the individual bank heterogeneity is uncorrelated with all the observed variables. Consequently, the Random effect model is specified thus:

$$
R O E_{i t}=\beta_{0}+\beta_{0}+\beta_{1} A T M_{i t}+\beta_{2} M B K_{i t}+\beta_{3} S I Z_{i t}+V_{i t}
$$

Where, $V_{i t}=\alpha_{i}+\varepsilon_{i t}$ is often called the composite error.

ROE $=$ Return on equity

$\mathrm{ATM}=$ number of ATM machines distributed by banks

MBK = Volume of Mobile banking

$\mathrm{SIZ}=$ Bank size. 


\section{Results and Interpretations}

Descriptive Statistics of the Data: Results in Table 2 show the descriptive statistics of the data to describe the relevance of the ATM and Mobile banking to banks' marketing efforts. Provision of ATM services is an important marketing strategy in the banking firms. The respondents from the banks' management staff were asked to indicate the extent to which they agreed with statements in relation to this. The standard deviation of the ROE was relatively low, suggesting stability of the banks' return on equity over the study period. The responses which were rated on five Likert scale were descriptively assessed and the results presented in Table 2. Provision of ATM services being utilized by banks ensures effective service delivery to customers. The respondents agreed that bank investment in ATM services ensures effective service delivery to customers with the mean rating of 3.74 .

This is likely since the use of ATM by customers generally reduce queues inside the banking halls and also offers customers opportunities to access banking services round the clock at convenient locations. The respondents agreed (3.89) that marketing efforts are made easier through ATM deployment. The respondents also agreed (Mean $=4.01$ ) that ATM services provided by banks contribute to the banks' profit through different charges arising from the use of ATM. The charges could come as a result of transaction notification messages sent to customers, transaction charges and other coded charges. The agreement of respondents $(M=3.86)$ that banks deploy ATM as part of strategic marketing channels underscores the importance of opening different transaction channels to customers in order to enhance the strategic marketing efforts of banks aimed at achieving improved performance.

Table 2: ATM Service Provision by Banking Firms

\begin{tabular}{lll}
\hline & Mean & Std. Dev. \\
\hline Our bank investment in ATM transactions ensures service delivery to our & 3.74 & 1.413 \\
customers & & \\
The bank service delivery is more enhanced through ATM service & 2.97 & 1.365 \\
ATM transactions contribute more to the bank profit & 4.01 & 1.219 \\
Our marketing efforts are made easier through ATM transactions & 3.89 & 1.119 \\
The bank made us of ATM as part of strategic marketing channels & 3.86 & 1.040 \\
\hline
\end{tabular}

Source: Authors' computation (2019)

Key: 5 = Strongly Agreed, 4 = Agreed, 3 = Not true, 2 = disagree, $1=$ strongly disagree.

The relevance of mobile banking to marketing strategies of the banks and performance is descriptively assessed based on the response of the respondents (Table 3). Most of the respondents agreed (Mean $=4.13$ ) that Mobile banking channel contributes to marketing initiatives of the bank. Further, the respondents agreed that mobile banking channel enhances the bank market efficiency (4.01), market expansion and contributes to profit level of the banks. This is expected since mobile banking is known to facilitate the provision of better services and products, which enhance customer satisfaction and at the same time, minimize operational costs of the banks. In addition, respondents agreed (3.48) that mobile banking contributes to customer retention strategy of banks.

Table 3: Mobile Banking Service Provision by Banking Firms

\begin{tabular}{lll}
\hline & Mean & $\begin{array}{l}\text { Standard } \\
\text { deviation }\end{array}$ \\
\hline Mobile banking contributes to strategic marketing initiatives of the bank & 4.13 & 1.215 \\
Mobile banking is an effective marketing channels for our banks & 3.04 & 1.293 \\
Mobile banking contributes significantly to performance outcome of our banks & 3.65 & 1.121 \\
Mobile banking enhances the bank market efficiency, market expansion and & 4.01 & 1.140 \\
banking technology improvement & & \\
Mobile banking contributes to our customer retention strategy & 3.48 & 1.293 \\
\hline
\end{tabular}

Source: Authors' computation (2019)

Key: 5 = Strongly Agreed, 4 = Agreed, 3 = Not true, 2 = disagree, $1=$ strongly disagree 
Findings from Secondary Data Analysis: Table 4 highlights the usage of ATM and mobile banking as service delivery channels including the performance measure which is represented by return on equity of the sampled banks. The average value of return on equity (ROE) of banking firms was $14.93 \%$. The bank with the least ROE had $0.40 \%$, while the bank with the highest ROE over the sample period had ROE of about $30.00 \%$. Statistics of mobile payment system show that the average value of mobile payment system over the sample period is $\$ 146.409$ billion at a maximum of $\$ 477.180$ billion for the bank with the highest mobile transaction over the period. The minimum value of mobile payment system was $\$ 1.270$ billion. The ATM transaction recorded the highest value over the sample period with an average value in billions of $N 2244.886$. The Jarque-Bera test of normality presented in the Table show that the null hypothesis of normality for the variables should not be rejected. Thus, all the variables are generally suitable for further regression analysis.

Table 4: Description of Variables Service Delivery Channels and Performance

\begin{tabular}{llll}
\hline & ROE & MPAY(Nb) & ATM (Ab) \\
\hline Mean & 14.931 & 146.409 & 2244.886 \\
Median & 17.600 & 31.510 & 1984.660 \\
Maximum & 30.000 & 477.180 & 4710.670 \\
Minimum & 0.400 & 1.2700 & 399.710 \\
Std. Dev. & 7.805 & 179.659 & 1499.847 \\
Skewness & -0.033 & 0.896 & 0.294 \\
Kurtosis & 2.212 & 2.156 & 1.837 \\
Jarque-Bera & 0.9115 & 5.723 & 2.475 \\
Probability & 0.634 & 0.0572 & 0.290 \\
Sum & 522.6000 & 5124.300 & 78571.00 \\
Sum Sq. Dev. & 2071.475 & 1097424.0 & 76484421 \\
\hline
\end{tabular}

Source: Authors' computation (2019)

The Hausman Test of the Study Variables: The decision on whether to use fixed or random effect for the estimation of the model was reached by conducting Hausman test. The standard deviation value (N179.66) of the variable suggests volatility or instability of mobile payment transaction over the sample period. The result presented in Table 5 indicates that fixed effect is appropriate for the estimation of the model to study service delivery channels and bank performance after rejecting the null hypothesis of random effect. The model was estimated using fixed effect because the result of the Hausman test showed a p-value of 0.0051 that is less than $5 \%$.

Table 5: Correlated Random Effects - Hausman Test

\begin{tabular}{llll}
\hline Test Summary & Chi-Sq. Statistic & Chi-Sq. d.f. & Prob. \\
\hline Cross-section random & 12.791705 & 3 & 0.0051 \\
\hline
\end{tabular}

Source: Authors' computation (2019)

The Estimated Model: This sub-section reports the estimated model of the effect of ATM and Mobile banking on bank performance. The result is presented in Table 6. The results show that ATM distributions to serve customer interest has a positive and significant effect on performance of banks $(\beta=0.048, P<0.05)$. The result suggests that raising performance in banks has a direct link with accessibility of products and services which is provided by proximity of transaction machines to customers. It is expected that proximity of service to customers would bridge distant barrier to banks most especially in areas with insufficient number of banks and where physical branches do not exist. Also, mobile payment $(\beta=0.870, \mathrm{P}<0.05)$ has a positive and significant effect on performance of banks; suggesting that performance of banks could be enhanced through mobile banking channel. Okiro and Ndungu (2013) defined mobile banking as the provision of bank financial services to customers through the help of mobile telecommunication.

Panel regression model was used to analyse the effect of the delivery channel variables on return on equity of the banks.This, according to Schofield and Kubin (2002), ensures convenience of banking to customers. The relative convenience brings about frequency of banking transaction and greater return to the banks. The 
findings of this study corroborate Lovelock and Young (2011) who found that each independent service delivery channel contributes to the performance objective of aggregated banks' sales growth, cost reduction, and increased means of linking the banks' products and services to the market, thus increasing return on equity. The parameter estimate of size included as a control variable also shows positive and significant $(\beta=$ $0.059, \mathrm{P}<0.05$ ) influence on bank performance. Size of the bank as represented by its asset can facilitate utilization of different service delivery channels which enables banks to reduce cost of operations, attract more customers and generate more revenue to boost its return on equity.

Table 6: Panel Regression Estimates of the Model

\begin{tabular}{|c|c|c|c|c|c|c|}
\hline & $\begin{array}{l}\text { Fixed effect } \\
\text { Coefficient }\end{array}$ & Std. error & t-stat & $\begin{array}{l}\text { Random Effect } \\
\text { Coefficient }\end{array}$ & Std. error & t-stat \\
\hline $\mathrm{C}$ & 17.181 & 3.036 & $5.658^{* *}$ & 21.008 & 3.489 & $6.021^{* *}$ \\
\hline ATM & 0.048 & 0.007 & $6.857^{* *}$ & 0.016 & 0.014 & 1.143 \\
\hline Mobile & 0.870 & 0.189 & $4.603^{* *}$ & 0.617 & 0.167 & $3.695^{* *}$ \\
\hline Size & 0.059 & 0.007 & $8.429 * *$ & 1.054 & 0.218 & $4.835^{* *}$ \\
\hline R-squared & 0.793 & & & 0.594 & & \\
\hline Adjusted $\mathrm{R}^{2}$ & 0.752 & & & 0.581 & & \\
\hline Log likelihood & -173.917 & & & & & \\
\hline F-statistics & 19.210 & & & 45.33249 & & \\
\hline Prob(F-statistic) & 0.000 & & & 0.000000 & & \\
\hline Hausman & $\begin{array}{l}12.792 \\
(0.0051)\end{array}$ & & & & & \\
\hline
\end{tabular}

Source: Authors' computation (2019)

\section{Conclusion and Recommendations}

This study examined the effect of marketing strategy involving the use of ATM and mobile payment on performance of banks in Nigeria. Both the ATM and mobile payment system are service delivery channels that are meant to attract and facilitate customer-bank relationship through ease of transaction and interaction with bank facilities and services. The descriptive analysis of the data from primary sources showed that bank management considered both the ATM and Mobile payment system as important marketing initiatives to raise the profit level of the banks. The overall findings of the study support the need for increased utilization of both the ATM and mobile payment system as service delivery channels. The results lead to the conclusion that both ATM and mobile payment system are significant marketing strategy to increasing return on equity of banks. Hence, Nigerian banks are encouraged to develop and introduce more efficient mobile banking products to serve customers without physical presence in the banking hall. Distribution of more ATMs at strategic locations such as markets and commercial centers will also be a step in the right direction. In addition, efficient provision of these banking services would require further investment in internet facilities to avoid failed transactions. Moreover, the provision of ATM and mobile banking services should be made at minimal cost if Nigerian banks will play meaningful roles in ensuring cashless economy.

\section{References}

Abaeneve, Z. C., Ogbulu, O. M. \& Ndugbu, M. O. (2013). Electronic Banking and Bank Performance in Nigeria. West African Journal of Industrial \& Academic Research, 6(1), 171-187.

Adewoye, J. O. (2013). Impact of Mobile Banking on Service Delivery in the Nigerian Commercial Banks. International Review of Management and Business Research, 2(2), 333-344.

Ali, P. I. \& Emenike, K. O. (2016). Impact of Automated Teller Machine on Banking Services Delivery in Nigeria: A stakeholder analysis. Cad. Ed. Tec. Soc., Inhumes, 9(1), 64-72.

Awinja, I. O. (2015). Service Delivery Channels and Operations Performance of Commercial Banks in Kenya, Unpublished Master Thesis. Submitted to the School of Business, University of Nairobi, Kenya.

Business Day. (2016, June 10). Systematically Important Banks Account for \$18.15trn Banking Sector Asset. Retrieved from www.businessdayonline.com. 
Dzombo, D. K., Kilika, J. M. \& Maingi, J. J. (2017). The Effect of Branchless Banking Strategy on the Financial Performance of Commercial Banks in Kenya. International Journal of Financial Research, 8(4), 167 183.

Imafidon, A. (2013). Challenges of E-banking and Payment Systems in Nigeria. Journal of the Chartered Institute of Bankers of Nigeria, Lagos, 39.

Jegede, C. A. (2014). Effects of Automated Teller Machine on the Performance of Nigerian Banks. American Journal of Applied Mathematics and Statistics, 2(1), 40-46.

Karmarkar, U., Pitbladdo, R. \& Awinja, I. O. (2019, 2015). Service Delivery Channels and Operations Performance of Commercial Banks in Kenya Unpublished M.sc Thesis, Submitted to the School of Business, University of Nairobi, Kenya.

Kiragu, M. (2017). Effects of E-banking on the Financial Performance of Kenyan Banks, Unpublished Bachelor of Business Administration. Submitted to the Department of Business Economics, University Of Applied Sciences, Kenya.

Kombe, S. K. \& Wafula, M. K. (2015). Effects of Internet Banking on the Financial Performance of Commercial Banks in Kenya: A case of Kenya Commercial Bank. International Journal of Scientific and Research Publications, 5(5), 1-10.

Lovelock, C. H., Young, R. F. \& Awinja, I. O. (2011, 2015). Service Delivery Channels and Operations Performance of Commercial Banks in Kenya, Unpublished Master Thesis. Submitted to the School of Business, University of Nairobi, Kenya.

Malhotra, P. \& Singh, B. (2009). The Impact of Internet Banking on Performance and Risk: The Indian Experience. Eurasian Journal of Business and Economics, 2(4), 43-62.

Mazwile, M. (2014). The Influence of Electronic Banking on Service Delivery Satisfaction to Customers: The Case of NMB bank in Tanzania. Unpublished Manuscript.

Mukhongo, H. O. O., Maokomba, C. \& Musiega, D. (2014). The Effect of Alternative Banking Channels on Profitability of Cooperative Bank of Kenya. The International Journal of Engineering and Science, 3(3), 29-34.

Oginni, S. O., Mohammed, A., El-Maude, J. G. \& Arikpo, I. A. (2013). E-banking and Bank Performance: Evidence from Nigeria. International Journal of Scientific Engineering and Technology, 2(8), 766-771.

Okafor, F. O. (2008). Valedictory Lecture" B \& F Publications, Enugu September, 2005.

Okiro, K. \& Ndungu, J. (2013). The Impact of Mobile and Internet Banking on Performance of Financial Institutions in Kenya. European Scientific Journal, 9(13).

Oloruntoyin, S. T. \& Olanloye, D. O. (2012). The Role of Information Communication Technology (ICT) on National Development. International Journal of Economic and Development Issues, 1\&2(11).

Onyekwelu, U. L. \& Onyeka, V. N. (2014). Financial Risk Management: A Review of the Role of the Central Bank of Nigeria. Research Journal of Finance and Accounting, 5(5), 40-52.

Schofield, E. \& Kubin, G. (2002). On Interfaces for Mobile Information Retrieval, Proceedings of the conference on Human-Computer Interaction with Mobile Devices (Mobile HCI), Pisa.

Shaikh, A. \& Karjaluoto, H. (2015). Mobile Banking Adoption: A Literature Review. Telematics and Informatics, 32(1), 111-126.

Tijani, J. A. \& Ilugbemi, A. 0. (2015). Electronic Payment Channels in the Nigeria Banking Sector and its impacts on National Development. Asian Economic and Financial Review, 5(3), 521-531.

Yamane, T. (1967). Statistics: An Introductory Analysis, (2nd Ed), New York: Harper and Row. 